\title{
SUBSTANTIATION OF THE CHOICE OF EXCIPIENTS WHEN DEVELOPING THE COMPOSITION OF “APISED" CAPSULES
}

\author{
O.S.Shpychak, O.I.Tikhonov \\ National University of Pharmacy
Key words: hard gelatin capsules; excipients; natural powder-like honey; medicinal plant raw material; pharmaceutical and technological properties

The aim of this work is to substantiate the qualitative composition and quantitative content of excipients; it will allow to provide optimal properties of the mass for capsulation when producing "Apised" capsules - a new original medicine developed on the basis of the standardized substance of natural powder-like honey and the medicinal plant raw material (the herb of garden balm, the cones of hop, the inflorescences of spike lavender). The results of the study of pharmaceutical and technological properties of active substances and their mixture have shown that it is impossible to obtain the mass for capsulation with satisfactory values of flowability and ability to settle without additional introduction of excipients. Antifriction substances were added to the mixture of active substances to improve these parameters. It has been found that addition of aerosil or its mixture with calcium stearate (3:1) in the amount of $2 \%$ is the most expedient for improvement of flowability of the mixture of active substances. To reduce ability to settle and prevent stratification of the mixture we have suggested to carry out pregranulation of the mixture of active substances. Starch (in the form of $5 \%$ solution) and polyvinylpyrrolidone, Plasdone K29/32 and Plasdone S629 in different amounts were used as wetting agents. The best values of flowability have been obtained when using Plasdone K29/32 in the amount of 5\%; at the same time ability to settle achieve acceptable values and the disintegration time of granules does not exceed acceptable limits. The optimal procedure of preparation of the mass for capsulation has been grounded: $5 \%$ Plasdone K29/32 solution is added to the mixture of the medicinal plant raw material, and granulation is carried out, then natural powder-like honey (NPH) and antiantifriction substances (aerosil or its mixture with calcium stearate (3:1)) are added to the granulate obtained. It is recommended to use in future when developing the technology of "Apised" capsules. The absence of necessity of adding humidity regulators into the composition of the mass for capsulation has been shown. The complex of the pharmaceutical and technological research conducted has allowed to substantiate the qualitative composition and quantitative content of excipients in the composition of the mass for capsulation under the conditions of pharmacy and industrial production of "Apised" capsules developed, as well as the procedure of obtaining the mass for capsulation.

To date physical overloads, tension of life rhythm, emotional stress, etc., can not be excluded from the sphere of the human professional activity. It quite often results in the partial loss of their working efficiency, the organism overexcitation, worsening of sleep and the general state and, therefore, in extended psychological and neurotic disorders [1]. Top records sport is not exception - solving the problem of treatment and rehabilitation of sportsmen with overload and the overtraining syndrome continues to remain one of key tasks in sport medicine $[2,10]$.

Under present-day conditions the training process of most of professional sportsmen takes place in the mode of increased tension and is characterized by continuous physical loads, which results in increasing the frequency of psychological, stress and psychotraumatic situations. In the period of intensive training there is also weakening of the immune system and the organism exhaustion being often the cause of change of its immunological reactivity. All mentioned above results in worsening of the sportsmen effectiveness.

In literature sources there is the information that in intensive sports activities the immune system is sub- jected, on the one hand, to training impact of physical and emotional load that extends its functionality, and on the other hand - to distress effect of extreme irritants occurring at the excessive loading [7].

To prevent these phenomena it is reasonable to use medicines, which are able to strengthen the body's immune system and reduce the irritating and psychoemotional loading without a doping effect.

It should be noted that medicines of the natural origin, in particular on the basis of beekeeping products [5], as well as herbal medicines (HM), are widely used lately in pharmaceutical practice; it is conditioned by their relative availability, efficiency and harmlessness, and in some cases by their competitiveness relative to their synthetic analogues.

Besides, apiproducts and components of medicinal plant raw material (MPR) are derivatives of the body natural metabolites by their chemical structure; by low toxicity and the minimal number of complications in therapeutic doses they show numerous pharmacological properties [5].

Therefore, along with hygienical and technological measures one of urgent tasks of sport medicine is the 
The pharmaceutical and technological parameters of the active substances of the "Apised" capsules and their mixture $(n=5, P=95 \%)$

\begin{tabular}{|l|c|c|c|c|c|c|}
\hline \multicolumn{1}{|c|}{ The name of the parameter } & $\begin{array}{c}\text { Garden balm } \\
\text { herb }\end{array}$ & Hop cones & $\begin{array}{c}\text { Spike } \\
\text { lavender } \\
\text { inflorescences }\end{array}$ & NPH & $\begin{array}{c}\text { The mixture } \\
\text { of APhl }\end{array}$ & $\begin{array}{c}\text { The dried } \\
\text { mixture } \\
\text { of APhl }\end{array}$ \\
\hline Flowability, $\mathrm{s} / 100 \mathrm{~g}$ & $81 \pm 3$ & $108 \pm 20$ & $112 \pm 21$ & $27.2 \pm 0.9$ & $92 \pm 1$ & $62 \pm 1$ \\
\hline Angle of natural slip, ${ }^{\circ}$ & $43-44$ & $52-53$ & $45-46$ & $36 \pm 37$ & $47-48$ & $45-46$ \\
\hline Bulk volume $\mathrm{V}_{0}, \mathrm{ml}$ & $352 \pm 2$ & $451 \pm 2$ & $371 \pm 2$ & $263 \pm 2$ & $365 \pm 2$ & $395 \pm 1$ \\
\hline Settled volume $\mathrm{V}_{10}, \mathrm{ml}$ & $281 \pm 2$ & $364 \pm 2$ & $287 \pm 2$ & $151 \pm 2$ & $275 \pm 2$ & $348 \pm 2$ \\
\hline Settled volume $\mathrm{V}_{500}, \mathrm{ml}$ & $236 \pm 2$ & $318 \pm 2$ & $244 \pm 2$ & $115 \pm 2$ & $238 \pm 2$ & $274 \pm 1$ \\
\hline Settled volume $\mathrm{V}_{1250} \mathrm{ml}$ & $231 \pm 2$ & $311 \pm 2$ & $236 \pm 2$ & $110 \pm 2$ & $224 \pm 2$ & $265 \pm 1$ \\
\hline Ability to settle $\mathrm{V}_{10}-\mathrm{V}_{500} \mathrm{ml}$ & 45 & 46 & 43 & 36 & 37 & 74 \\
\hline Density of bulk product $\mathrm{m} / \mathrm{V}_{0}, \mathrm{~g} / \mathrm{ml}$ & $0.284 \pm 0.002$ & $0.222 \pm 0.002$ & $0.270 \pm 0.002$ & $0.38 \pm 0.03$ & $0.274 \pm 0.002$ & $0.253 \pm 0.002$ \\
\hline $\begin{array}{l}\text { Density of settled product } \mathrm{m} / \mathrm{V}_{1250} \\
\text { g/ml }\end{array}$ & $0.433 \pm 0.002$ & $0.322 \pm 0.002$ & $0.424 \pm 0.002$ & $0.91 \pm 0.05$ & $0.446 \pm 0.002$ & $0.377 \pm 0.002$ \\
\hline
\end{tabular}

search, development and manufacturing application of natural medicines, which are able to increase the body's resistance to extreme influences and psychological disorders.

The studies on development of the composition and technology of medicines for application in sport medicine, mainly on the basis of the standardized substances of beekeeping products are carried out. One of these medicines is the original medicine in the form of capsules under the conditional name "Apised" developed on the basis of natural powder-like honey (NPH) and the medicinal plant raw material (the herb of garden balm, the cones of hop, the inflorescences of spike lavender). It is recommended to application with the purpose of rehabilitation acceleration of the body's functions of sportsmen worsened as the result of overstrain and overtraining, and also as the additional source of vitamins, organic and mineral acids, essential oils, alkaloids, flavonoids, phenolic compounds, antioxidants, etc. [6, 8].

The choice of capsules as a dosage form with oral application, in the first place, is related to such advantages as accuracy of dose, comfort in application and storage, portability, etc., as well as high bioavailability of active pharmaceutical ingredients $(\mathrm{APhI})$, which are the components of the medicine developed.

The aim of this work is to substantiate the qualitative composition and quantitative content of excipients; it will allow to provide optimal pharmaceutical and technological properties of the mass for capsulation when producing "Apised" capsules developed under conditions of pharmacy and industrial production.

\section{Materials and Methods}

The objects of the research were the following samples of APhI of "Apised" capsules: the herb of garden balm - Herba Melissa officinalis L. (the registration certificate No.UA/8919/01/01, batch 60612) manufactured by "Liktravy" PJSC (Zhytomyr, Ukraine); the cones of hop - Strobuli Humuli lupuli L. (the registration certificate No.UA/11477/01/01, batch 003) manufactured by "Liktravy" PJSC (Zhytomyr, Ukraine); the inflorescences of spike lavender - Flores Lavandulae angustifolia Mill. cultivated on the territory of Nikitsky Botani- cal Garden of UAAS; NPH (the Ukrainian specification 01.2-02010936-001:2007; the changes No.1:2013 to the Ukrainian specification 01.2-02010936-001:2007) obtained by freeze drying under conditions of "Biolik" JSC (Kharkiv) using "Virtis" production equipment (USA) [6].

Our research was carried out on the basis that one capsule would contain $0.225 \mathrm{~g}$ of active substances [6]. Talc, aerosil of A-380 grade (the State Standard 1492277), starch (the State Standard 7699-78), calcium stearate (the Ukrainian specification 22942814.003-2000), Plasdone K29/32, Plasdone S629 and polyvinylpyrrolidone (PVP) [9, 11-19] were used as excipients.

The flowability was studied for APhI, their mixture and the masses for capsulation obtained, as well the bulk volume, ability to settle, density of bulk and settled product were determined according to the procedure of SPhU (SPhU $1^{\text {th }}$ ed., art. 2.9.15, art. 2.9.16) $[3,4]$. Besides, the value of the angle of natural slip was measured by means of a goniometer.

When studying the moisture absorption APhI, their mixture and masses for capsulation were introduced into the preliminary weighted weighing bottles with the diameter of $29 \pm 0.5 \mathrm{~mm}$ and the height of $35 \pm 0.5 \mathrm{~mm}$, the weighing bottles were placed into the desiccator with the diameter of $140 \mathrm{~mm}$; the permanent relative air humidity at the level of $100 \%$ created with purified water was supported in the desiccator at the temperature of $20^{\circ} \mathrm{C}$. In a certain period of time the samples of the substances studied were taken from weighing bottles, and the moisture content was determined in them by means of a "Sartorius"humidity analyser of MA-150 grade produced by "Sartorius" AG group company, Germany.

\section{Results and Discussion}

The results of studying the pharmaceutical and technological properties of APhI and their mixtures (flowability, angle of natural slip, bulk volume, ability to settle, density of bulk product) indicate that it is impossible to obtain the mass for capsulation with satisfactory values of flowability and ability to settle without additional introduction of excipients (Tab. 1).

Therefore, to improve these parameters such antifriction substances as talc, starch, Plasdone K29/32, as 
The pharmaceutical and technological parameters of the masses for capsulation of "Apised" capsules developed ( $\mathrm{n}=5, \mathrm{P}=95 \%)$

\begin{tabular}{|l|c|c|c|c|c|}
\hline \multicolumn{1}{|c|}{ The name of parameter } & $\begin{array}{c}\text { The mixture } \\
\text { of APhl, talc } \\
\text { and starch }\end{array}$ & $\begin{array}{c}\text { The mixture } \\
\text { of APhl, } 5 \% \\
\text { of Plasdone } \\
\text { K29/32, } \% \text { of } \\
\text { calcium stearate }\end{array}$ & $\begin{array}{c}\text { The mixture } \\
\text { of APhl, 2\% } \\
\text { of aerosil }\end{array}$ & $\begin{array}{c}\text { The mixture } \\
\text { of APhl, } \\
2 \% \text { of calcium } \\
\text { stearate }\end{array}$ & $\begin{array}{c}\text { The mixture } \\
\text { of APhl, } 0.5 \% \\
\text { of calcium } \\
\text { stearate, } 1.5 \% \\
\text { of aerosil }\end{array}$ \\
\hline Flowability, $\mathrm{s} / 100 \mathrm{~g}$ & $115.5 \pm 0.6$ & $33 \pm 6$ & $25 \pm 2$ & $33 \pm 2$ & $24 \pm 2$ \\
\hline Angle of natural slip, ${ }^{\circ}$ & $45-46$ & $38-39$ & $35-36$ & $38-39$ & $34-35$ \\
\hline Bulk volume $\mathrm{V}_{0^{\prime}} \mathrm{ml}$ & $378 \pm 2$ & $381 \pm 2$ & $398 \pm 2$ & $396 \pm 2$ & $394 \pm 2$ \\
\hline Settled volume $\mathrm{V}_{10}, \mathrm{ml}$ & $265 \pm 2$ & $273 \pm 2$ & $276 \pm 2$ & $278 \pm 2$ & $275 \pm 2$ \\
\hline Settled volume $\mathrm{V}_{500} \mathrm{ml}$ & $234 \pm 2$ & $239 \pm 2$ & $241 \pm 2$ & $245 \pm 2$ & $240 \pm 2$ \\
\hline Settled volume $\mathrm{V}_{1250}, \mathrm{ml}$ & $214 \pm 2$ & $220 \pm 2$ & $221 \pm 2$ & $218 \pm 2$ & $218 \pm 2$ \\
\hline Ability to settle $\mathrm{V}_{10}-\mathrm{V}_{500} \mathrm{ml}$ & 31 & 34 & 35 & 33 & 35 \\
\hline Density of bulk product $\mathrm{m} / \mathrm{V}_{0}, \mathrm{~g} / \mathrm{ml}$ & $0.265 \pm 0.002$ & $0.262 \pm 0.002$ & $0.251 \pm 0.002$ & $0.253 \pm 0.002$ & $0.254 \pm 0.002$ \\
\hline $\begin{array}{l}\text { Density of settled product } \mathrm{m} / \mathrm{V}_{1250} \\
\text { g/ml }\end{array}$ & $0.467 \pm 0.002$ & $0.455 \pm 0.002$ & $0.452 \pm 0.002$ & $0.459 \pm 0.002$ & $0.459 \pm 0.002$ \\
\hline
\end{tabular}

well as calcium stearate and aerosil in the amount of $0.5-2.0 \%$ were added to the mixture of active substances. The results obtained are given in Tab. 2 and Fig. 1.

The results of the pharmaceutical and technological research show that addition of aerosil or its mixture with calcium stearate $(3: 1)$ in the amount of $2 \%$ is the most expedient for improvement of flowability of the mixture of active substances. Addition of calcium stearate or its mixture with Plasdone K29/32 also increases flowability of the mass for capsulation, however, less effectively. Further increase of the content of antifriction substances is not expedient as the parameters of flowability do not significantly improve. It should be noted that introduction of calcium stearate also allows to avoid adhesion of a powder-like mixture to the capsule-filling machine in the process of capsulation.

The results of the experimental research indicate that in spite of improvement of flowability when adding the excipients to the mixture of APhI, ability to settle of the masses for capsulation obtained continues to be unsatisfactory large. Moreover, stratification of the mixture is fixed visually, it is confirmed by the considerable differences of pharmaceutical and technological parameters of $\mathrm{APhI}$. Therefore, in order to prevent occurrence

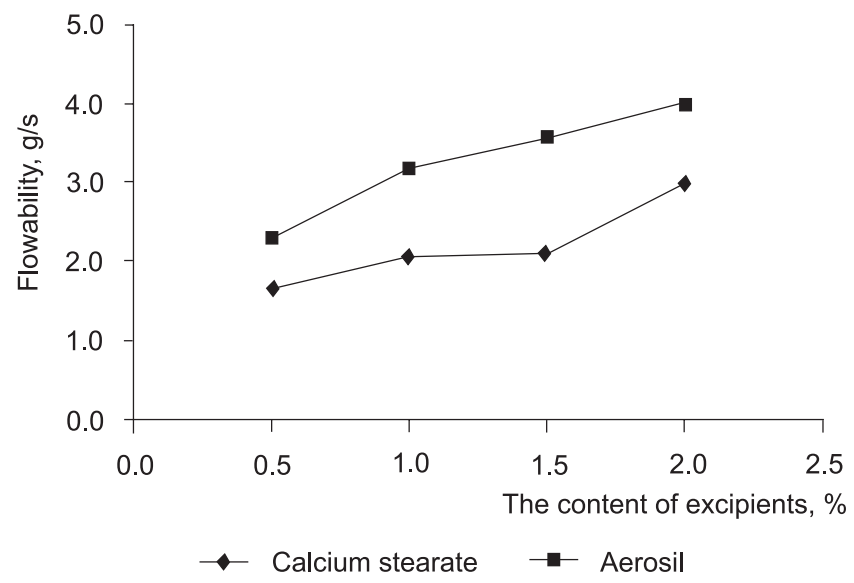

Fig. 1. Dependence of flowability of the mass for capsulation on the calcium stearate and aerosil content. of this phenomenon we have suggested to carry out pregranulation of the mixture of active substances. Thus, starch (in the form of 5\% solution) and PVP, Plasdone K29/32 and Plasdone S629 in different amounts were used as wetting agents. The results of the flowability research of the granular masses for capsulation obtained are given in Fig. 2, they indicate that the best values of flowability were obtained when using Plasdone K29/32 as a wetting agent in the amount of 5\%. Thus, ability to settle decrease and achieve acceptable values. It is also necessary to note that the disintegration time of granules does not exceed acceptable limits.

The use of $5 \%$ starch solution as a wetting agent results in adherence of the granulate obtained, and it makes impossible its application for manufacturing of "Apised" capsules developed.

The next stage of our research was the choice of the optimal order of mixing and granulation of active and excipients. Three variants of the procedure of obtaining the mass for capsulation were studied:

1) $5 \%$ solution of Plasdone K29/32 was added to the mixture of $\mathrm{APhI}$ and antifriction substances (aerosil or its mixture with calcium stearate (3:1)), and granulation was carried out;

2) $5 \%$ solution of Plasdone K29/32 was added to the mixture of MPR and antifriction substances (aerosil or its mixture with calcium stearate (3:1)), and granula-

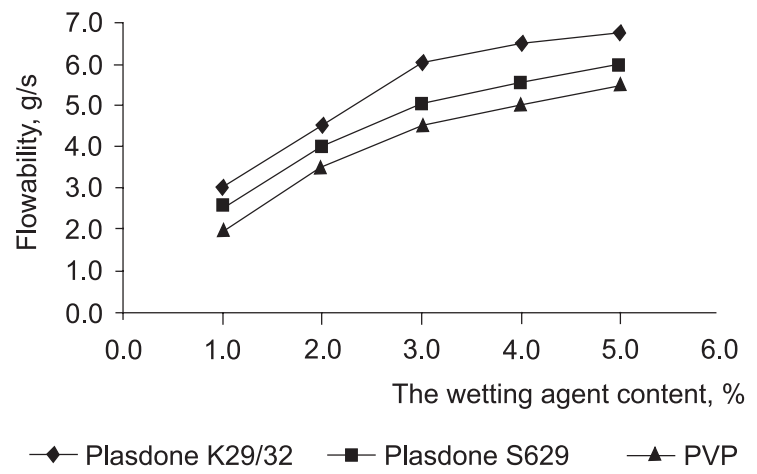

Fig. 2. Dependence of flowability of the mass for capsulation on the wetting agents content. 


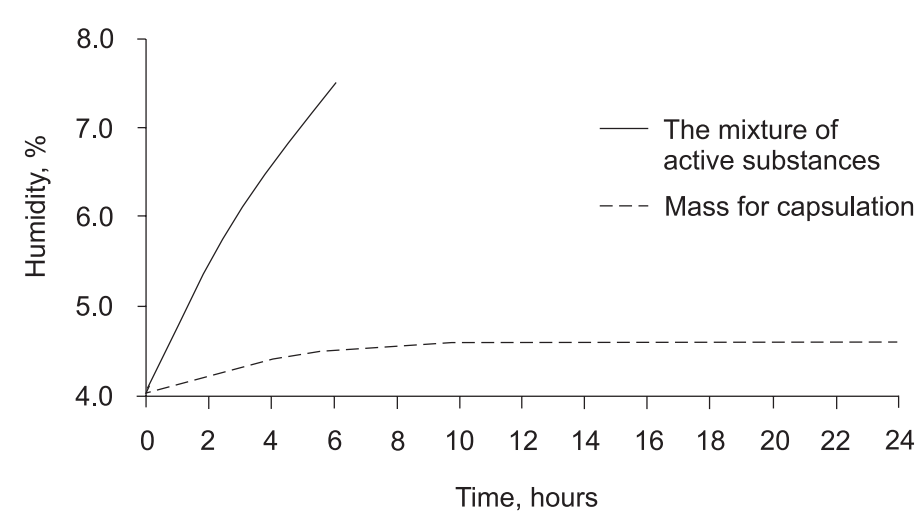

Fig. 3. Dependence of moisture absorption on time for "Apised" capsules developed.

tion was carried out, then NPH was added to the granulate obtained;

3) $5 \%$ solution of Plasdone K29/32 was added to the mixture of MPR, and granulation was carried out, then NPH and antifriction substances (aerosil or its mixture with calcium stearate (3:1)) were added to the granulate obtained.

It has been found that optimal pharmaceutical and technological parameters were obtained under conditions of application of the third variant of the procedure of preparing the mass for capsulation. It is recommended to use in future when developing the technology of "Apised" capsules.

The results of the experiment has also shown that the mixture of $\mathrm{APhI}$ has unsatisfactory parameters of moisture absorption (Fig. 3). Therefore, it is necessary to introduce a humidity regulator to the composition of the mass for capsulation. One of the most used humidity regulators is aerosil. We suggested it for introduction to the composition of the mass for capsulation to improve its flowability at the previous stage of our research. In this connection, moisture absorption of the masses obtained for capsulation was also studied. The results obtained indicate that there is no need of further addition of humidity regulators (Fig. 3).
Thus, the complex of pharmaceutical and technological research conducted has allowed to substantiate the qualitative composition and quantitative content of excipients in the composition of the mass for capsulation under the conditions of pharmacy and industrial production of "Apised" capsules developed (aerosil $-1.5 \%$, calcium stearate $-0.5 \%$, Plasdone K29/32 - 5\% or aerosil - 2\%, Plasdone K29/32-5\%), as well as the procedure of obtaining the mass for capsulation.

\section{CONCLUSIONS}

1. The complex of the pharmaceutical and technological research has been carried out in order to substantiate the qualitative composition and quantitative content of excipients under the conditions of pharmacy and industrial production of "Apised" capsules developed.

2. The expediency of introduction of antifriction substances into the composition of the mass for capsulation has been determined, and their optimal amount in the process of production of "Apised" capsules: aerosil $1.5 \%$, calcium stearate $-0.5 \%$ or aerosil $-2 \%$ has been experimentally substantiated.

3. The necessity of pre-granulation of the mass for capsulation has been shown, the choice of a wetting agent, its amount and the procedure of obtaining the granular mass for capsulation in the course of production of the medicine developed have been substantiated.

\section{REFERENCES}

1. Батышева Т.Т., Сквориов Д.В., Труханов А.И. Современные технологии диагностики и реабилитации в неврологии и ортопедии. - М.: Медика, 2005. - 256 с.

2. Гладков В.Н. Некоторые особенности заболеваний, травм, перенапряжений и их профилактика в спорте выстих достижений. - М.: Советский спорт, 2007. - 152 c.

3. Держсавна фармакопея Украйни / Державне підприємство «Науково-експертний фармакопейний центр». 1-е вид. - Х.: РІРЕГ, 2001. - 556 c.

4. Держсавна фармакопея Украйни / Державне підприсмство «Науково-експертний фармакопейний центр». 1-е вид. - Х.: РІРЕГ, 2001. - Доп. 1. - 2004. - 520 c.

5. Мед натуральный в медицине и фармации (происхождение, свойства, применение, лекарственные препаратьl): Монография / А.И.Тихонов, С.А.Тихонова, Т.Г.Ярныхх, О.С.Шпичак, Е.Е.Богуцкая. Под ред. А.И.Тихонова. -Х.: Оригинал, 2010. -263 с.

6. Пат. на винахід 105243 Украӥна, МПК51 А 61 К 9/48 (2006.01), А 61 K 35/64 (2006.01), А 61 K 36/18 (2006.01), А 61 K 36/53 (2006.01), А 61 P 25/20 (2006.01). Лікувально-профілактичний засіб у формі капсул із седативною дією / О.С.Шпичак, О.І.Тихонов; заявник і патентовласник Національний фармацевтичний університет, Шпичак О.С. - №a2012 05332. Заявл.: 28. 04. 2012. Опубл.: 25. 04. 2014. Бюл. №8. -5 c.

7. Сапин М.Р., Ткачук М.Г. // Вестник Рос. АМН. - 2001. -№12. - С. 20-22. 
8. Шиичак О.С., Яковлєва Л.В., Шаповал О.М. // УБФЖ. - 2012. - №5-6 (22-23). - C. 78-83.

9. Allen L., Ansel H. Pharmaceutical Dosage Forms and Drug Delivery Systems. - 10 ${ }^{\text {th }}$ ed. - Philadelphia: Baltimore: NY: Wolters Kluwer, 2014. - 794 p.

10. Augustsson R.S., Augustsson J., Thomee R. // Scand. J. Med. Sci. Sports. - 2006. - Vol. 16. - P. 433-440.

11. Blacker A.J., Williams M.T. Pharmaceutical Process Development: Current Chemical and Engineering Challenges. - Cambridge: The Royal Society of Chemistry (RSC) Publishing, 2011. - 354 p.

12. Cox Gad S. Pharmaceutical Manufacturing Handbook. Production and Processes. - $1^{\text {st }}$ ed. - Wiley-Interscience, 2008. - 1384 p.

13. Gibson M. Pharmaceutical Preformulation and Formulation. - Informa, 2001. - 596 p.

14. Langley C., Belcher D. Pharmaceutical Compounding and Dispensing. - Pharmaceutical Press, $2008 .-214$ p.

15. Niazi S.K. Handbook of Pharmaceutical Manufacturing Formulations: Compressed Solid Products. - Vol. 1. CRC, 2004. $-328 \mathrm{p}$.

16. Niazi S.K. Handbook of Pharmaceutical Manufacturing Formulations: Uncompressed Solid Products. - Vol. 2. CRC, 2004. - $232 p$.

17. Qiu Y., Chen Y. Developing Solid Oral Dosage Forms. Pharmaceutical Theory \& Practice. - $1^{\text {st }}$ ed. - Academic Press, 2009. - 978 p.

18. Rowe R.C., Sheskey P.J., Quinn M.E. Handbook of Pharmaceutical Excipients. - 6 ${ }^{\text {th }}$ ed. - London: Chicago: Pharmaceutical Press and American Pharmacists Association, 2009. - 917 .

19. William A. Pharmaceutical Manufacturing Encyclopaedia. - $3^{d}$ ed. - William Andrew Publishing, 2008. $3846 p$.

\section{ОБҐРУНТУВАННЯ ВИБОРУ ДОПОМІЖНИХ РЕЧОВИН ПРИ РОЗРОБЦІ СКЛАДУ КАПСУЛ «АПІСЕД» \\ О.С.Шпичак, O.I.Тихонов \\ Ключові слова: тверді желатинові капсули; допоміжні речовини; мед натуральний порошкоподібний; лікарська рослинна сировина; фрармакотехнологічні властивості} Метою даної роботи було обгрунтування якісного складу та кількісного вмісту допоміжних речовин, що дозволить забезпечити оптимальні властивості маси для капсулювання при виробництві капсул «Апісед» - нового оригінального лікарського препарату, розробленого на основі стандартизованої субстанції меду натурального порошкоподібного та лікарської рослинної сировини (трави меліси лікарської, шишок хмелю звичайного, суцвіть лаванди вузьколистої). Результати вивчення фрармакотехнологічних властивостей діючих речовин та їх суміші показали, що без додаткового введення допоміжних речовин неможливо отримати масу для капсулювання із задовільними показниками плинності та здатності до усадки. 3 метою покращення плинності додавали антифрикційні речовини, встановлено, що найбільш доцільним для поліпшення плинності суміші діючих речовин є додавання аеросилу або його суміші з кальцію стеаратом (3:1) у кількості 2\%. 3 метою зменшення здатності до усадки та запобігання розшаруванню суміші запропоновано проводити попереднє гранулювання суміші діючих речовин. Як зволожувачі було використано крохмаль (у вигляді 5\% розчину) та полівінілпіролідон, Plasdone K29/32 і Plasdone S629 у різних кількостях. Найбільш оптимальні показники плинності були отримані у випадку використання Plasdone K29/32 у кількості 5\%, при цьому здатність до усадки досягає прийнятних значень, а час розпадання гранул не перевищує допустимих меж. Обгрунтовано оптимальну процедуру приготування маси для капсулювання - до суміші лікарської рослинної сировини додають 5\% розчин Plasdone K29/32 та проводять гранулювання, потім до отриманого грануляту додають мед натуральний порошкоподібний та антифрикційні речовини, яку рекомендовано використовувати надалі при розробці технології капсул «Апісед». Показано відсутність необхідності додавання вологорегуляторів до складу маси для капсулювання. Комплекс проведених фрармакотехнологічних досліджень дозволив обгрунтувати якісний склад та кількісний вміст допоміжних речовин у складі маси для капсулювання при виготовленні в аптечних та виробництві в промислових умовах розроблених капсул «Апісед», а також процедуру отримання маси для капсулювання.

\section{ОБОСНОВАНИЕ ВЫБОРА ВСПОМОГАТЕЛЬНЫХ ВЕЩЕСТВ ПРИ РАЗРАБОТКЕ СОСТАВА КАПСУЛ «АПИСЕД» \\ О.С.Шпичак, А.И.Тихонов}

Ключевые слова: твердые желатиновые капсулы; вспомогательные вещества; мед натуральный порошкообразный; лекарственное растительное сырье; фрармакотехнологические свойства

Целью данной работы было обоснование качественного состава и количественного содержания вспомогательных веществ, что позволит обеспечить оптимальные свойства массы для капсулирования при производстве капсул «Аписед» - нового оригинального лекар- 
ственного препарата, разработанного на основе стандартизированной субстанции меда натурального порошкообразного и лекарственного растительного сырья (травы мелиссы лекарственной, шишек хмеля обыкновенного, соцветий лаванды узколистной). Результаты изучения фрармакотехнологических свойств действующих веществ и их смеси показали, что без дополнительного введения вспомогательных веществ невозможно получить массу для капсулирования с удовлетворительными показателями текучести и способности к усадке. С целью улучшения текучести добавляли антифрикционные вещества, установлено, что наиболее целесообразным для улучшения текучести смеси действующих веществ является добавление аэросила или его смеси с кальция стеаратом (3:1) в количестве 2\%. С целью уменьшения способности к усадке и предотвращения расслоения смеси предложено проводить предварительное гранулирование смеси действующих веществ. В качестве увлажнителей были использованы крахмал (в виде 5\% раствора) и поливинилпирролидон, Plasdone K29/32 и Plasdone S629 в различных количествах. Наиболее оптимальные показатели текучести были получены в случае использования Plasdone K29/32 в количестве 5\%, при этом способность к усадке достигает приемлемых значений, а время распада гранул не превышает допустимых пределов. Обоснована оптимальная процедура приготовления массы для капсулирования - к смеси лекарственного растительного сырья добавляют 5\% раствор Plasdone K29/32 и проводят гранулирование, затем к полученному грануляту добавляют мед натуральный порошкообразный и антифрикционные вещества, которую рекомендуется использовать в дальнейшем при разработке технологии капсул "Аписед». Показано отсутствие необходимости добавления влагорегуляторов в состав массы для капсулирования. Комплекс проведенных фрармакотехнологических исследований позволил обосновать качественный состав и количественное содержание вспомогательных веществ в составе массы для капсулирования при изготовлении в аптечных и промышленных условиях разработанных капсул «Аписед», а также процедуру получения массы для капсулирования. 